\title{
Chromosome Mosaicism in a Mentally Retarded Mother and Her Daughter
}

\author{
CARMEN B. LOZZIO*, GUILLERMO R. JAUREGUI, JUAN C. SCORNAVACHI, \\ and MIGUEL A. GAMBIN
}

\section{From Laboratory of Genetics I. Faculty of Sciences, University of Buenos Aires, and 'Hospital Rivadavia', Sala XVI, Buenos Aires, Argentina}

Mosaicism for a chromosome of group G (21-22) has been described in many patients with typical Down's syndrome (Clarke, Edwards, and Smallpeice, 1961 ; Blank, Gemmell, Casey, and Lord, 1962; Smith, Therman, Patau, and Inhorn, 1962; Nichols, Coriell, Fabrizio, Bishop, and Bogg, 1962; Weinstein and Warkany, 1963; Lindsten, Alvin, Gustavson, and Fraccaro, 1962; Hayashi, Hsu, and Chao, 1962) and in some non-mongoloid people with varied clinical conditions (Biesele, Schmid, and Lawlis, 1962; Turner and Jennings, 1961; Fitzgerald, 1962; Dunn, Ford, Auersperg, and Miller, 1961; Zellweger, Mikamo, and Abbo, 1962; Sparkes, Veomett, and Wright, 1966).

Familial transmission of an extra chromosome from one generation to the next is relatively rare, but has been detected in some cases in which a mosaic trisomy G-normal was found in the apparently normal parent of a mongol child (Smith et al., 1962; Blank et al., 1962; Weinstein and Warkany, 1963; Verresen, van den Berghe, and Creemers, 1964; Ferrier, 1964). However, repeated mosaicism in two generations is, to our knowledge, very infrequent. It is the purpose of this paper to report the occurrence of mosaicism in a mother and her 17year-old daughter. Both were mentally retarded but did not exhibit physical signs of mongolism.

\section{Case Reports}

The mother was a 38-year-old, obese, mentally retarded, white woman, whose weight was $60 \mathrm{~kg}$. (132 lb.) and height $150 \mathrm{~cm}$. (5 ft.). On psychological testing, a high degree of oligophrenia was found. Biological maturation corresponded to 6 years of age (Bender's Classification), and a mental age of $8 \frac{1}{2}$ was found (Terman-Merrill test). The urinary excretion of $5-\mathrm{OH}$

\footnotetext{
Received November 24, 1966.

* Present address: Memorial Research Center and Hospital, University of Tennessee, Knoxville, Tennessee, U.S.A.
}

indolacetic acid while on a normal diet was determined in two different samples and gave the following results: $2 \mathrm{mg}$. for a urine volume of $1000 \mathrm{ml}$. and $1 \mathrm{mg}$. for $1200 \mathrm{ml}$. (Udenfriend, Titus, and Weissbach, 1955, which gives a normal value of 6-8 mg.).

The father was a normal white man, 41 years old.

There were four sibs: an apparently normal 6-year-old boy, two mentally retarded boys of 13 and 14 , and a mentally retarded girl of 17 . The 13-year-old boy was subject to epileptic attacks which consisted of clonic convulsions of the left arm and left side of the face, followed by loss of consciousness for 2 or 3 minutes. The electroencephalogram was normal. The diagnosis made by the neurologist was of a syndrome of retarded maturation of the central nervous system. The 14-year-old boy had never been examined by a physician, but the father said he had convulsive attacks and a mental development similar to his 13-year-old brother.

The 17-year-old girl was mentally retarded, obese, hypertensive, and hypothyroid. Her weight was $52 \cdot 2$ kg. (114.8 lb.) and height $150 \mathrm{~cm}$. (5 ft.). Blood pressure was $160 / 100 \mathrm{~mm}$. Hg. The facies was not mongoloid and the skin was dry and coarse. Her breasts, axillary, and pubic hair were normally developed and she has had regular menstrual periods since the menarche at 12 years of age (Fig. 1). On psychological testing at age 15, an IQ of 22 was found. Goodenough's test showed a mental age of 7 years 5 months, while Terman-Merrill's test showed a mental age of 7 years 2 months. Biological maturation corresponded to 5 years of age (Bender's test).

Hypothyroidism was confirmed by chemical studies. Serum protein-bound iodine was $3.7 \mu \mathrm{g} . / 100 \mathrm{ml}$., ${ }^{131}$ I uptake was $10 \%$ at 3 hours, $24 \%$ at 24 hours, and $20 \%$ at 48 hours, and a basal metabolic rate of $-25 \%$ was found. The electrocardiogram was normal. The value of urinary 17 -ketosteroids was $7.36 \mathrm{mg}$. in 24 hours, the urinary excretion of hydroxycorticoids was 1.72 $\mathrm{mg}$. in 24 hours, and the urocitogram was trophic. No phenylpyruvic acid was found. The blood serotonin levels were $1280 \mathrm{~m} \mu \mathrm{g}$. and $1980 \mathrm{~m} \mu \mathrm{g} . / 1000 \mathrm{ml}$. (Udenfriend, Weissbach, and Clark, 1955) with normal values of $100 \mathrm{~m} \mu \mathrm{g}$. to $300 \mathrm{~m} \mu \mathrm{g} . / 1000 \mathrm{ml}$.). The urinary excretion of 5-OH indolacetic acid was studied while on a normal diet, and $3 \mathrm{mg}$. were detected in $900 \mathrm{ml}$. urine. 


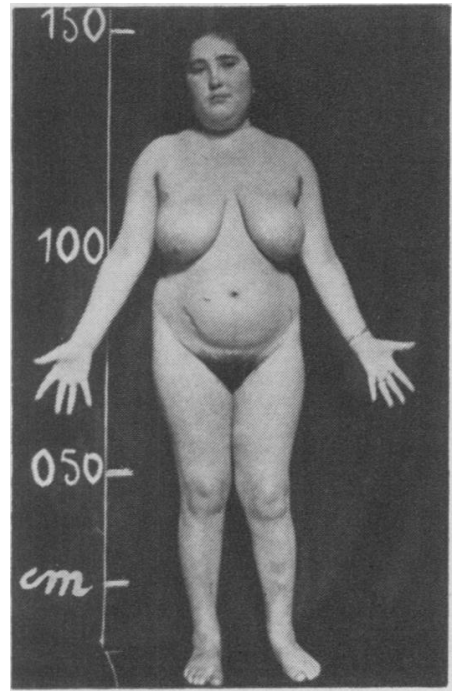

FIG. 1. Photograph of the daughter at the age of 15 years.

After a diet with high tryptophan content ( 4 bananas plus normal diet) the $5-\mathrm{OH}$ indolacetic acid values were still low: $2 \mathrm{mg}$. in a sample of $650 \mathrm{ml}$. and $5 \mathrm{mg}$. in another of $800 \mathrm{ml}$. After loading with $3 \mathrm{~g}$. tryptophan the excretion of $5-\mathrm{OH}$ indolacetic acid increased only to $7 \mathrm{mg}$. for $600 \mathrm{ml}$.

\section{Cytogenetic Findings}

The chromosomes of the mother were studied in one short-term culture of peripheral blood (Moorhead, Nowell, Mellman, Battips, and Hungerford, 1960). The daughter's chromosomes were analysed in two blood cultures and one bone-marrow sample prepared according to the following method: $12 \times 10^{6}$ cells were cultured in $10 \mathrm{ml}$. of TC 199 plus $30 \%$ human AB serum for 24 hours; colchicine to a final concentration of $5 \times 10^{-6} \mathrm{M}$ was added for 5 hours, followed by treatment with hypotonic Hank's solution for $30 \mathrm{~min}$., fixation in 3:1 absolute alcohol-acetic acid, and staining with Giemsa or Unna's blue.

TABLE

SUMMARY OF CHROMOSOME ANALYSIS OF THE MOTHER AND DAUGHTER

\begin{tabular}{|c|c|c|c|c|c|c|c|}
\hline Case & Culture & $\begin{array}{l}\text { No. of } \\
\text { Cells } \\
\text { Counted }\end{array}$ & $\mathrm{Ch}_{44}$ & $\begin{array}{l}\text { romosome } \\
\text { Counts } \\
454647\end{array}$ & $\begin{array}{c}\text { Percent- } \\
\text { age of } \\
\text { Trisomic } \\
\text { Cells }\end{array}$ & $\begin{array}{r}\mathrm{No} \\
\mathrm{Ce} \\
\mathrm{Kar} \\
\text { typ } \\
454\end{array}$ & $\begin{array}{l}\text { of } \\
\text { ells } \\
\text { ryo- } \\
\text { ped } \\
464\end{array}$ \\
\hline Mother & Blood & 117 & 1 & 48919 & $16 \cdot 2$ & 4 & 96 \\
\hline \multirow[t]{2}{*}{ Daughter } & $\begin{array}{l}\text { Blood } \\
\text { Blood } \\
\text { Bone- } \\
\text { marrow }\end{array}$ & $\begin{array}{l}48 \\
58 \\
15 \\
\end{array}$ & $\begin{array}{l}0 \\
0 \\
0\end{array}$ & $\begin{array}{rrrr}0 & 38 & 10 \\
1 & 47 & 10 \\
0 & 11 & 4 \\
\end{array}$ & $19 \cdot 8$ & $\begin{array}{l}- \\
-\end{array}$ & $\begin{array}{l}3 \\
3 \\
2\end{array}$ \\
\hline & Total & 121 & 0 & 19624 & & - & 811 \\
\hline
\end{tabular}

Chromosome counts are summarized in the Table. In the blood culture obtained from the mother 117 cells were examined. A count of 46 chromosomes was found in 89 cells, and 47 chromosomes were present in 19 cells. Four cells with 45 chromosomes and one with 44 chromosomes presented a random loss of a chromosome of group C (6-12). In nine cells with 46 chromosomes, a normal female chromosome complement was found, and in six cells with 47 chromosomes, an extra small acrocentric chromosome was observed.

In the three cultures obtained from the daughter, 121 cells were studied: 96 cells with 46 chromosomes, 24 cells with 47 chromosomes, and one with 45 chromosomes were found. The analysis of the karyotype of eight cells with 46 chromosomes showed a normal female chromosome complement, and 11 cells with 47 chromosomes exhibited an extra small acrocentric chromosome similar to the one present in the cells with 47 chromosomes of the mother.

The extra small acrocentric chromosome was approximately of the same size as the chromosomes of group G(21-22-Y), but it could not always be matched with either pair 21 or 22 (see Fig. 2, 3, 4, and 5). The long arms were similar to those observed in the chromosomes of group $G$, but the short arms appeared to be like those of pair 18 rather than satellites. This chromosome was never found to enter into association with other acrocentrics, and morphologically it is very difficult to decide if it is an extra chromosome 21,22 , a $Y$, or a fragment of another chromosome.

Positive sex chromatin was found in the buccal smears, and only single Barr bodies of normal size were found in all the positive cells.

\section{Discussion}

Several examples of trisomy G (21-22) without clinical mongolism have been described but they do not represent a characteristic syndrome which might be ascribed to trisomy 22 . The first case was an example of the Sturge-Weber syndrome (Hayward and Bower, 1960). However, in other patients with this syndrome studied by the same authors (1961), as well as in two analysed by Lehmann and Forssman (1960), a normal karyotype was found. On the other hand, Patau, Therman, Smith, Inhorn, and Picken (1961) found a translocation in one of three patients with Sturge-Weber syndrome. A segment morphologically similar to a 21 or 22 chromosome was found translocated to a chromosome 13-15, and these authors postulated that the syndrome could be caused by a partial trisomy of an autosome which was probably not a number 22 . The extra fragment could not be detected when it was translocated into a big submetacentric chromosome but was observed when it was translocated into an acrocentric chromosome (case of Patau et al., 1961) or when it was present as an extra centric fragment, morphologically similar to a chromosome $G$, as in Hayward and 


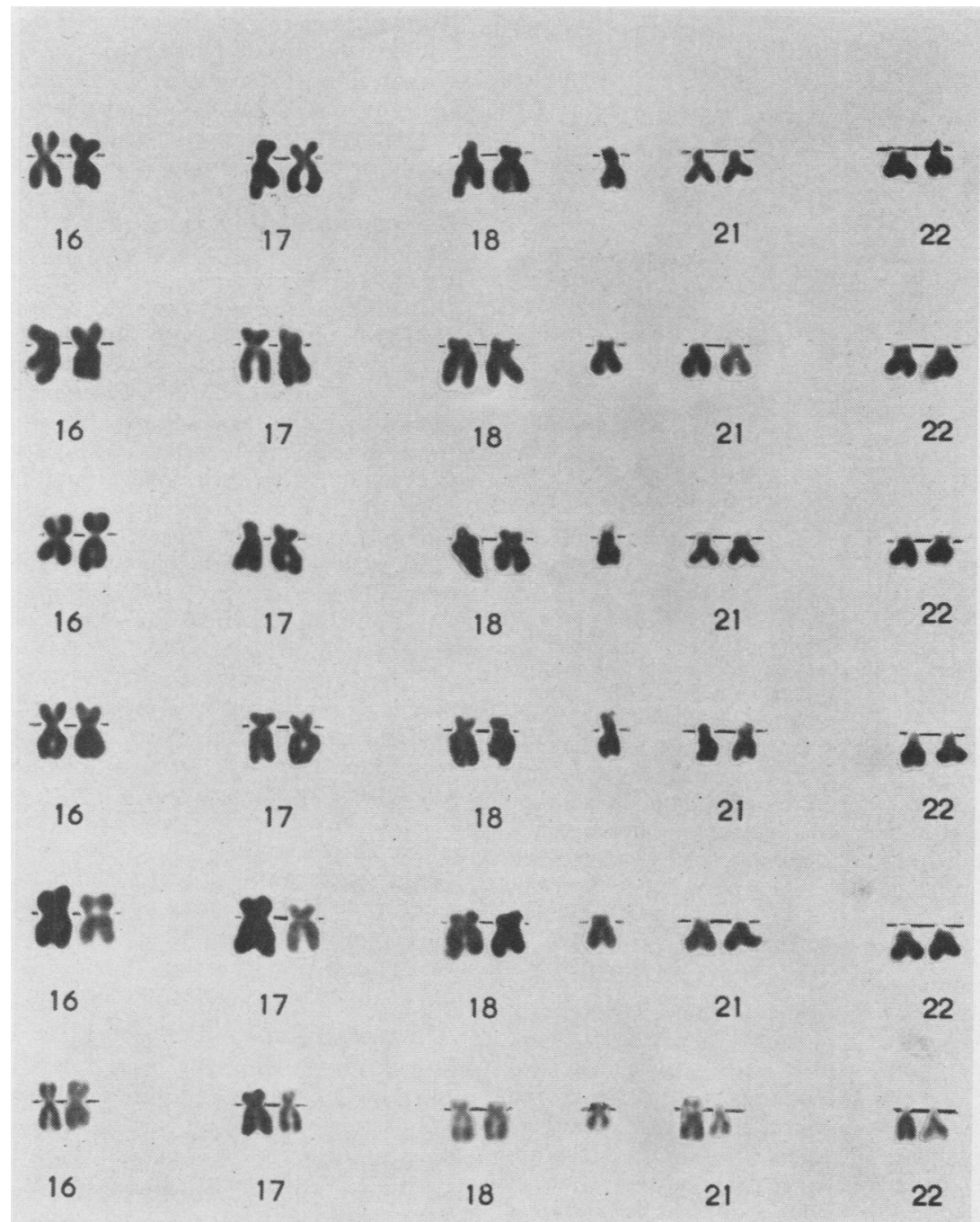

Fig. 2. Groups $\mathrm{E}$ and $\mathrm{G}$ from six cells showing the additional G-like chromosome. The three upper lines are from karyotypes of the mother and the other three are from karyotypes of the daughter.

Bower's case. Other published cases reported as possible trisomies 22 or trisomy $\mathrm{G}$ without mongolism may be explained in the same form.

The low frequency of non-mongoloid $\mathrm{G}$ trisomics, as compared with mongolism, and the fact that trisomy $G$ has been found in spontaneously aborted foetuses (Carr, 1965), might be accounted for if most of the cases with trisomy 22 died during embryogenesis. On the other hand, the many different syndromes observed in non-mongol $G$ trisomics indicate that only a few cases are probably true trisomy 22 or mosaics for such trisomy, while many others may be partial trisomies for a fragment of another autosome. Examples of morphological $\mathrm{G}$ trisomics, in which a chromosome other than 22 was considered to be involved, have been described by several authors. Gustavson, Hagberg, Finley, and Finley (1962) found an extra acrocentric fragment in two sibs with mental deficiency, micrognathia, microcephaly, cleft palate, and low-set malformed ears. Due to the clinical findings, the authors considered that the small acrocentric was a fragment of a chromosome of group D (13-15) or E (17-18). In another case in which a mosaic for an acrocentric larger than a 21 but smaller than a 13-15 (Crawfurd, 1961) was observed in a mentally retarded child with 


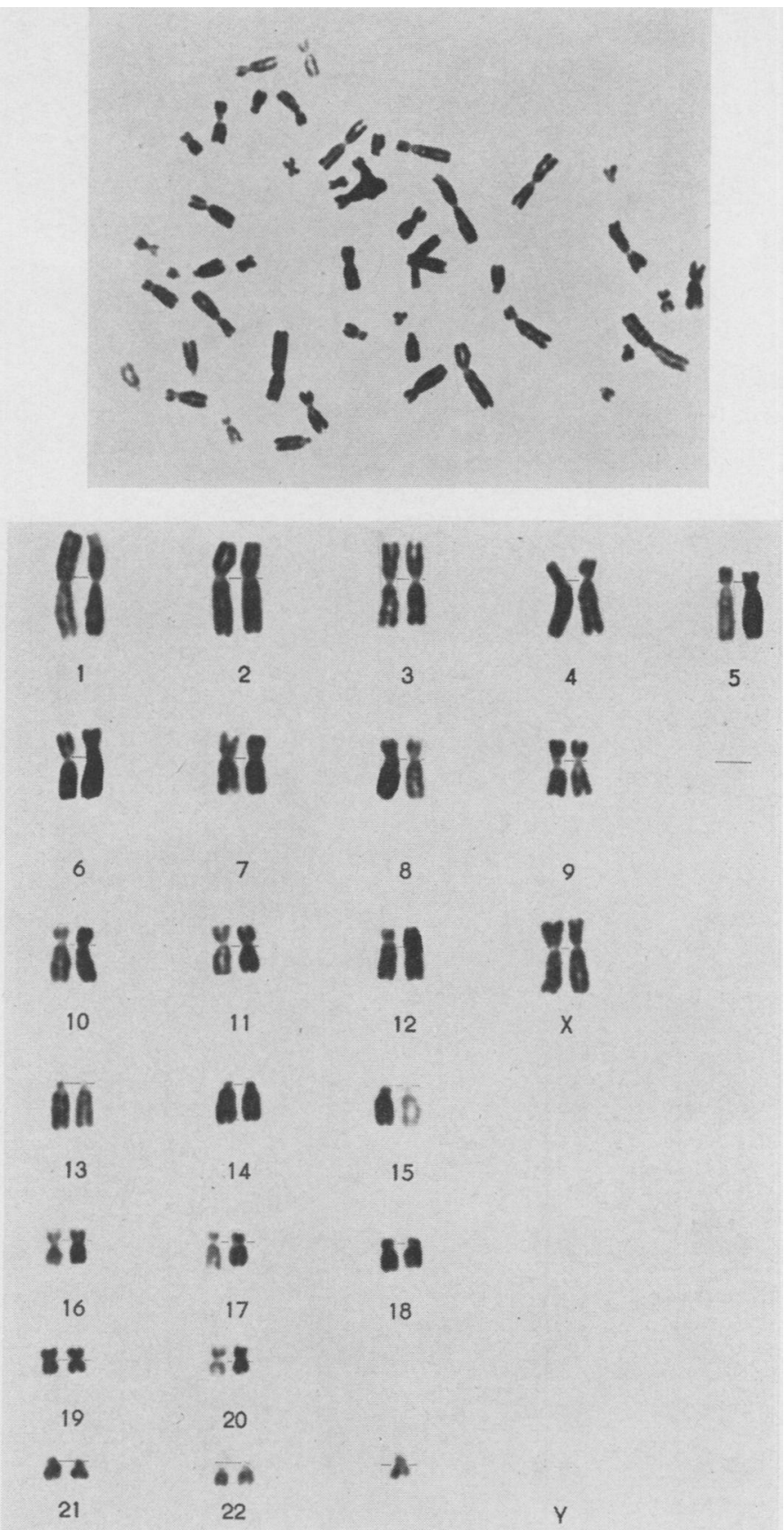

Fig. 3. Metaphase and karyotype from cultured lymphocyte of the mother showing the extra G-like chromosome.

low-set ears, micrognathy, interventricular septal defect, hydronephorosis, and hydroureter, the author suggested that the extra chromosome could be a deleted 17-18. The possibility that an extra acro- centric chromosome might be part of a translocation morphologically similar to a 21-22 chromosome was postulated by Vislie, Wehn, Brøgger, and Mohr (1962), in two mentally retarded sibs with malformed 


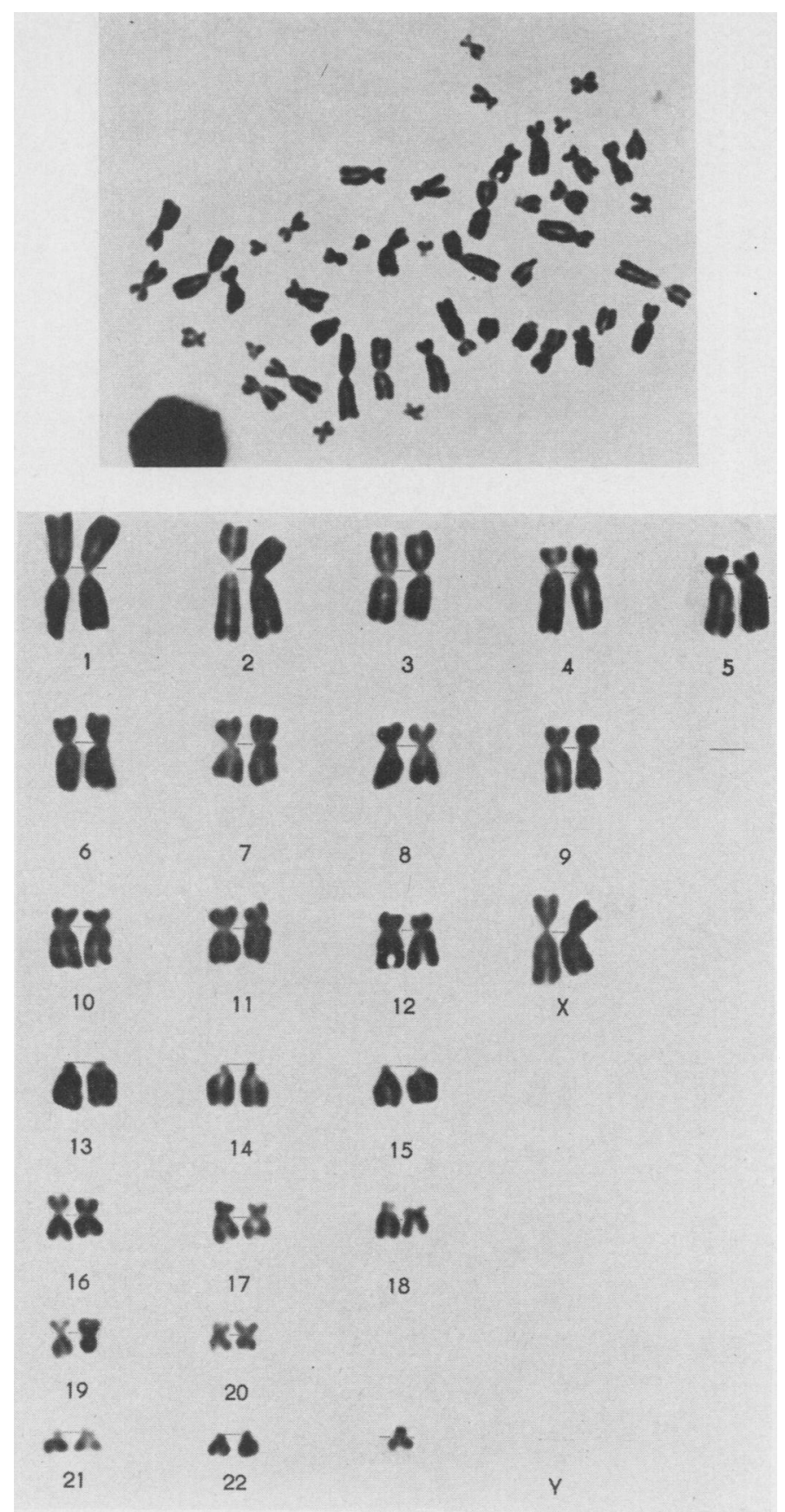

Fig. 4.-Metaphase and karyotype of a cell from the daughter's blood culture.

cranium, epicanthi, low-set ears, and generalized hypotonia, because the karyotype of the mother showed a reciprocal translocation between two chromosomes of the group D (13-15) and E (17-18).
The new chromosome, $T_{1}$, was morphologically similar to one of group C (6-12), while the $T_{2}$ was like a G (21-22).

In our cases, it is difficult to determine if the extra 


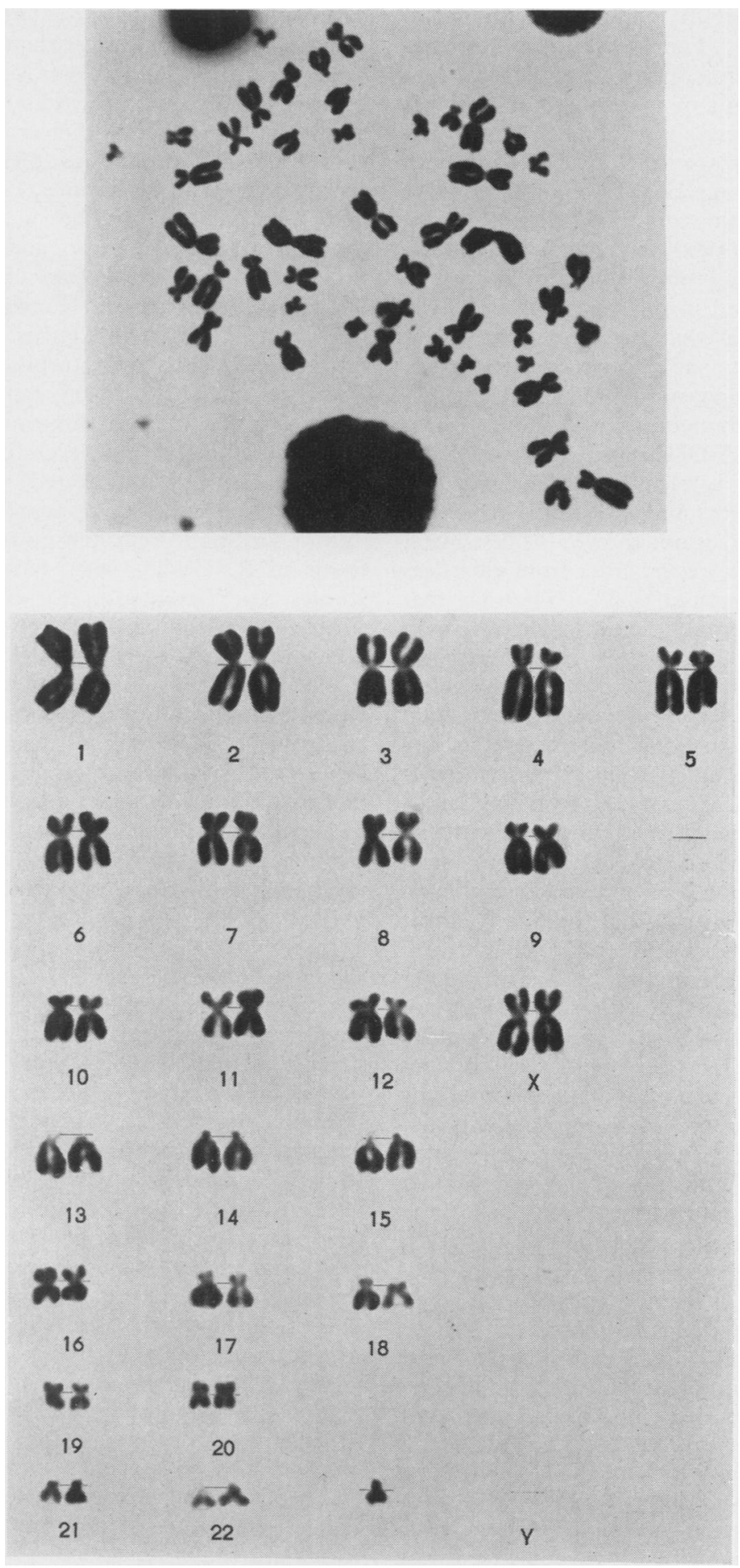

Fig. 5. Metaphase and karyotype of a cell from the daughter's bone-marrow. 
acrocentric is a number 21 , a 22 , or a fragment of another chromosome. The possibility of mosaicism for trisomy 21 seems to be very unlikely. Not only were physical signs of mongolism absent, but high blood serotonin levels were found. The presence of low 5-OH indolacetic acid excretion in both mother and daughter agrees with the alteration of tryptophan metabolism described by Jerome, Lejeune, and Turpin (1960) in mongolism. However, the high blood serotonin levels, in contrast to the low values observed in mongols ( $\mathrm{Tu}$ and Zellweger, 1965), suggested that the alteration in our patients was related to an abnormal excretion of serotonin or a reduced conversion into $5-\mathrm{OH}$ indolacetic acid, while in mongolism it has been shown that the conversion of 5-OH tryptophan into $5-\mathrm{OH}$ typtamine (serotonin) is blocked. Mosaicism for trisomy 22 cannot be excluded, because the true phenotype of trisomy 22 is not known. The clinical features of our cases, however, differ from all others described as possible trisomies 22 . The idea that the extra chromosome might represent a Y cannot be accepted because both cases are phenotypic females with no sign of sterility or intersexuality. On the other hand, the female phenotype and mental retardation might support the hypothesis that the extra chromosome is a deleted $\mathrm{X}$ and the two cases represent mosaics $\mathrm{XX} / \mathrm{XXx}$. Unfortunately, autoradiography was not performed to find out if the small acrocentric was a late replicating chromosome, but the fact that only one Barr body was found in all the positive sex chromatin cells of the buccal smear is an argument against such a possibility. Moreover, the size of the extra chromosome, which is smaller than the short arms of the X, makes it necessary to postulate that two breaks have occurred to give rise to such a fragment. On the contrary, a fragment representing the short arm of another chromosome such as one of the group B (4-5) of some chromosomes of group C (6-12) as well as one of the arms of chromosome 16 could be morphologically similar to one chromosome of group G(21-22-Y). A single break near the centromere and the loss of the acentric fragment might originate a G-like chromosome fragment. Its presence in addition to a normal chromosome complement would represent a partial trisomy for a region of a chromosome whose phenotypic expression might be different if compared with the syndromes produced by trisomy $\mathrm{G}(21-22), \mathrm{E}(17-18)$, or $\mathrm{D}$ (13-15). This seems to be the most likely explanation for our cases. Not only does the phenotype differ from the known trisomy syndromes, but the morphology of the extra chromosome can be explained if we consider it as a centric fragment originated by deletion of one arm of an autosome or one of the two new chromosomes resulting from a reciprocal translocation.

Familial transmission of a centric fragment has been reported by Smith, Steinberger, Steinberger, and Perloff (1965) and other examples are known of extra fragments present in addition to normal karyotypes (Ishmael and Laurence, 1965; Frøland, Holst, and Terslev, 1963). The occurrence of familial mosaicism, however, is rare and has been described previously only in a few instances. TzonevaManeva, Bosajieva, and Petrov (1966) observed mosaicism XY/XYY in a father and his son affected by an idiopathic hypertrophic osteoarthropathy. Zellweger and Abbo (1965) reported a family with one mosaic XO/XY and three mosaics for a balanced translocation $\mathrm{D} / \mathrm{D}$ in three different generations. The last authors postulated that an autosomal dominant gene could be responsible for the abnormal mitosis leading to repeated mosaicism. The hypothesis of R. Grell (1962), based on experimental studies in Drosophila, is another explanation suggested for the unusual families with association of non-disjunction and translocation as well as for the occurrence of non-disjunction during meiosis when a small duplicated chromosome is present in the gonads (R. Grell and Valencia, 1964). Small duplicated chromosomes are also known to be lost during division of somatic cells in Drosophila (E. Grell, 1966, personal communication) and our cases might represent one example, in man, of the same mechanisms that are known to occur in Drosophila.

In sum, we think that the extra chromosome observed in the two members of the family reported here is a fragment of an autosome. It might have been originated during gametogenesis of one of the parents of the mother, and by non-disjunction passed to the zygote of the mother together with a normal chromosome complement. During embryogenesis it was probably lost in many of her somatic cells giving rise to the normal cell line observed in the blood cultures. Nevertheless, the fragment present in the gonadal cells of the mother might have been transmitted to her three abnormal descendants. Unfortunately we could only study one of the three retarded sibs, due to lack of cooperation of the family, but we know that the three presented the same degree of mental retardation, and at least the mother and daughter showed a clone of cells with the same extra chromosome that we consider as a fragment of a longer autosome. The frequency of such fragments in humans is still unknown, but they might represent the only viable forms of trisomy for regions of chromosomes whose complete trisomy is lethal. 


\section{Summary}

Mosaicism 46/47 was observed in a mentally retarded girl 17 years old, and in her mother, who was also mentally deficient. The girl presented with obesity, hypertension, and hypothyroidism. Increased serotonin levels were found in the blood, but decreased excretion of $5-\mathrm{OH}$ indolacetic acid was demonstrated in the urine. The mother was also obese and exhibited low 5-OH indolacetic acid excretion. Two other sibs were mentally retarded but were not studied cytogenetically. The karyotypes of the mother, studied in blood culture, and the chromosomes of the daughter, obtained from one bone-marrow and two blood cultures, showed a normal cell line and one trisomic for a small acrocentric chromosome. The extra chromosome appeared to be, morphologically, one of group $\mathrm{G}(21-22)$. However, it seems very unlikely that it is a number 21 , due to the absence of signs of mongolism and the presence of high blood serotonin levels, in contrast to the low serotonin values found in mongolism. The possibility that it represents a chromosome 22 cannot be completely excluded, but the clinical findings are different from all the others reported in cases interpreted as 22 trisomics. The idea that it might be a $\mathrm{Y}$ is not supported by the phenotype, while the size of the extra chromosome and the fact that only one Barr body was found in the cells with positive sex chromatin seems to rule out the hypothesis of a deleted X. Therefore, it is considered that the most likely possibility is that it represents a centric fragment of an autosome.

We wish to thank Drs. R. F. Grell, M. Bender, $R$. Lange, and A. Chernoff for helpful discussion of the manuscript, and Mrs. Estela Heineman de Licen for technical assistance.

This study was supported in part by a grant (N 991c) from the Argentine National Research Council.

\section{REFERENCES}

Biesele, J. J., Schmid, W., and Lawlis, M. G. (1962). Mentally retarded schizoid twin girls with 47 chromosomes. Lancet, 1, 403. Blank, C. E., Gemmell, E., Casey, M. D., and Lord, M. (1962). Mosaicism in a mother with a mongol child. Brit. med. $\mathcal{F} ., 2$, 378.

Carr, D. H. (1965). Chromosome studies in spontaneous abortions. Obstet. and Gynec., 26, 308.

Clarke, C. M., Edwards, J. H., and Smallpeice, V. (1961). 21-trisomy normal mosaicism in an intelligent child with some mongoloid characters. Lancet, 1, 1028.

Crawfurd, M. d'A. (1961). Multiple congenital anomaly associated with an extra autosome. ibid., 2, 22.

Dunn, H. G., Ford, D. K., Auersperg, N., and Miller, J. R. (1961). Benign congenital hypotonia with chromosomal anomaly. Pediatrics, 28, 578.
Ferrier, S. (1964). Enfant mongolien-parent mosaique: étude de deux familles. Génét. hum., 13, 315.

Fitzgerald, P. H. (1962). A possible supernumerary chromosome associated with dystrophia myotonica. Lancet, 2, 456.

Frøland, A., Holst, G., and Terslev, E. (1963). Multiple anomalies associated with an extra small autosome. Cytogenetics, 2, 99.

Grell, R. F. (1962). A new hypothesis on the nature and sequence of meiotic events in the female of drosophila melanogaster. Proc. nat. Acad. Sci. (Wash.), 48, 165.

- and Valencia, J. I. (1964). Distributive pairing and aneuploidy in man. Science, 145, 66.

Gustavson, K. H., Hagberg, B., Finley, S. C., and Finley, W. H. (1962). An apparently identical extra autosome in two severely retarded sisters with multiple malformations. Cytogenetics, 1, 32.

Hayashi, T., Hsu, T. C., and Chao, D. (1962). A case of mosaicism in mongolism. Lancet, 1, 218.

Hayward, M. D., and Bower, B. D. (1960). Chromosomal trisomy associated with the Sturge-Weber syndrome. ibid., 2, 844.

- and - (1961). The chromosomal constitution of the Sturge-Weber syndrome. ibid., 1, 558.

Ishmael, J., and Laurence, K. M. (1965). A probable case of incomplete trisomy of a chromosome of the 13-15 group. F. med. Genet., 2, 136.

Jerome, H., Lejeune, J., and Turpin, R. (1960). Étude de l'excrétion urinaire de certains métabolites du tryptophane chez les enfants mongoliens. C.R. Acad. Sci. (Paris), 251, 474.

Lehmann, O., and Forssman, H. (1960). Chromosomes in the Sturge-Weber syndrome. Lancet, 2, 1450.

Lindsten, J., Alvin, A., Gustavson, K. H., and Fraccaro, M. (1962). Chromosomal mosaic in a girl with some features of mongolism. Cytogenetics, 1, 20.

Moorhead, P. S., Nowell, R. C., Mellman, W. J., Battips, D. M., and Hungerford, D. A. (1960). Chromosome preparations of leukocytes cultured from human peripheral blood. Exp. Cell Res., 20, 613.

Nichols, W. W., Coriell, L. L., Fabrizio, D. P. A., Bishop, H. C., and Bogg, T. R. (1962). Mongolism with mosaic chromosome pattern. F. Pediat., 60, 69.

Patau, K., Therman, E., Smith, D. W., Inhorn, S. L., and Picken, B. F. (1961). Partial-trisomy syndromes. I. Sturge-Weber's disease. Amer. F. hum. Genet., 13, 287.

Smith, D. W., Therman, E. M., Patau, K. A., and Inhorn, S. L. (1962). Mosaicism in mother of two mongoloids. Amer. F. Dis. Child., 104, 534.

Smith, K. D., Steinberger, E., Steinberger, S., and Perloff, W. (1965). A familial centric chromosome fragment. Cytogenetics, 4, 219.

Sparkes, R. S., Veomett, I. C., and Wright, S. W. (1966). Trisomy $\mathrm{G}$ without Down's syndrome. Lancet, 1, 270.

Tu, J.-B., and Zellweger, H. (1965). Blood-serotonin deficiency in Down's syndrome. ibid., 2, 715.

Turner, B., and Jennings, A. N. (1961). Trisomy for chromosome 22. ibid., 2, 49.

Tzoneva-Maneva, M. T., Bosajieva, E., and Petrov, B. (1966). Chromosomal abnormalities in idiopathic osteoarthropathy. ibid., 1, 1000.

Udenfriend, S., Titus, E., and Weissbach, H. (1955). The identification of 5-hydroxy-3-indoleacetic acid in normal urine and a method for its assay. F. biol. Chem., 216, 499.

-, Weissbach, H., and Clark, C. T. (1955). The estimation of 5-hydroxytryptamine (serotonin) in biological tissues. ibid., 215, 337.

Verresen, H., van den Berghe, H., and Creemers, J. (1964). Mosaic trisomy in phenotypically normal mother of mongol. Lancet, 1, 526.

Vislie, H., Wehn, M., Brøgger, A., and Mohr, J. (1962). Chromosome abnormalities in a mother and two mentally retarded children. ibid., $\mathbf{2}, 76$.

Weinstein, E. D., and Warkany, J. (1963). Maternal mosaicism and Down's syndrome (mongolism). F. Pediat., 63, 599.

Zellweger, H., and Abbo, G. (1965). Familial mosaicism attributable to a new gene. Lancet, 1, 455.

- Mikamo, K., and Abbo, G. (1962). Two cases of nonmongoloid trisomy G. Ann. paediat. (Basel), 199, 613. 